\title{
THE INFLUENCE OF TRANSFORMATIONAL LEADERSHIP, INTERPERSONAL COMMUNICATION, AND ORGANIZATIONAL COMMITMENT OF PUBLIC SERVICE QUALITY IN BNP2TKI
}

\author{
Abdul Ghofar \\ State University of jakarta \\ Email: abdghofar_im11s3@mahasiswa.unj.ac.id \\ Wibowo \\ State University of Jakarta \\ Email: wibowo303@yahoo.co.id ${ }^{2}$ \\ Burhanuddin Tola \\ State University of Jakarta \\ Email: burhanudiin.tola@gmail.com
}

\begin{abstract}
The purpose of this research is to measure direct and indirect influence of transformational leadership, interpersonal communication, and organizational commitment for public service quality in BNP2TKI. This study used survey method, and included in quantitative research. Sample is calculated using Slovin method, is set minimum sample for 140 people, taken by systematic random sampling. Method of data collection by dissemination research instrumens to selected respondents. Method of data analysis using path analysis. The result of the research shows that there are positive direct influence of transformational leadership, interpersonal communication and organizational commitment toward the quality of public service in BNP2TKI. Transformational leadership and interpersonal communication has the positive direct influence for organizational commitment. Transformational leadership has the positive direct influence for interpersonal communication. Transformational leadership has the biggest direct influence for the quality of public service of BNP2TKI.
\end{abstract}

Keywords: The Quality of Public Service, Transformational Leadership, Interpersonal Communication, Organizational Commitment.

\section{INTRODUCTION}

Good governance is a fundamental in suistanability of every instituition (Aras, Güler \& David Crowther;2008). Good governance able to increase the public trust. In the middle of global competition that becomes more strict, government institution is demanded to able applying the system of Good governance more and more good (good corporate governance).

The National Board Of Placement And Protection Of Indonesian Migrant Worker (BNP2TKI) as one of the government institution is expected to able increase the productivity of performance from time to time. To be able to increase the productivity of performance, BNP2TKI has to have good strategic plan and right on target according to vision and mission that has been set. Strategy Bussines Plan that is done will create bussines process activity performance and the distribution and resource utilization that can be applied to create vission and mission of BNP2TKI.

BNP2TKI in the effort to increase public service quality for sure, is not easy, because not regardless from instituiton internal dan external influence. Internal influences of BNP2TKI involve employee work motivation, leader behavior and power, interpersonal communication, organizational commitment, working culture, mindset, birocracy behavior, birocracy performance, employee ability, employee competency, employee experience, employee responsibility, disposition and birocracy structure and also organization communication climate and information flow, organization restructurisation, facility 
planning, radical changing, restructurisation, information technology utilization and service efficiency, emporwement birocracy official, changing process, conflict management, working design and working stress (Hardiansyah, 2014). External factor that influence public service quality of BNP2TKI could come from government policy, government regulation, government intervention, implementation of service integration policy, social control and society monitoring, politic party, external culture, consumer data and other stakeholder

Generally, society opinion measures that public service quality of birocracy official is not maximal, it could be seen from epmolyee performance at working the task is not maximal, complicated public service procedure, complex, strict, slow, wasting time, there is no solving matter, paying, not transparent, unresponsive employee behavior or friendly to society and etc, including society appreciation to BNP2TKI performance. Therefore researcher want to know whatever factors that could influence public service quality in BNP2TKI seen by internal factor i.e, transformational leadership, interpersonal communication, and organizational commitment.

Mudji Rahardjo and Purbudi (1997) explain the succesfull and the failure of an organization or instituion are determined by leadership, effective leadership form will impact to company/organization advance, meanwhile communication factor that is not running well (include to interact or having relation with data user/consumer) could cause service quality decline, and also organizational commitment factor that show how an individual identify $\mathrm{him} /$ herself within organization and attached within organization purpose" (Robert Kreitner dan Anggelo Kinichi, 2003) include vision and mission and also target of BNP2TKI that have been set. This research aim to measure causality realitionship between transformational leadership, interpersonal communication and organizational commitment to public services quality in BNP2TKI related to the placement and protection services of Indonesian workers.

\section{LITERATURE REVIEW}

\section{Public Service Qualitiy}

Public service quality has been explained by some expertises such as Fandy Tjiptono (2001:51), Kotler (2002:83), Kuno Schedler dan Jurg Felix (2000:125). Model of service quality measurement is developed by Parasuraman, Zeithaml dan Berry (1990), and also Gronroos (1984). Model Parasuraman states a service that is offered begin from management perception by it consumer expectation, then this management perception is designed to become current specification quality and is delivered to consumer through service and also external communication. Model that was explained by Gronroos (1984) stated this model relate to expereince to service by consumer and is compared to its expectation. Service qualities according to Parasuraman, and partners (1998) were measured through 5 (five) dimenton i.e tangible, reliability, responsiveness, assurance dan empathy.

\section{Transformational Leadership}

The definition of leadership refer to Daft (2002:51), Stoner in Nanang Fattah (2008:88), Irham Fahmi (2002:8), Colquitt (2011:499), George R. Terry that are quoted by Miftah Thoha (2010:5), A. Dale Timpe (2008:8), Kartini Kartono (2003:48), Gary Yukl (2007:3), Andrew J. Dubrin (2009:4), Bertocci (2009:7) and Allan Lee et. al (2015). Transformasional leadership is developed for the first time by James MacGregor Burns (1978), then is developed by Bernard M. Bass and Ronald E. Reggio (2006:3), Robbins and Coulter (1999:508), Ancok (2012:130). Leadership according to Robbins and Coulter (1999) is that as leaders which give their own consideration, intelectual stimulation, and have charisma.

Researcher synthesizes transformational leadership is leader that could stimulate and inspire its follower so cause the awareness to achieve the maximal result and also develope leadership capacity through indicators : (1) Idealized Influence, (2) Inspirational motivation, (3) Intellectual stimulation, and (4) Individual consideration. 


\section{Interpersonal Communication}

Agus M. Hardjana (2003:5) state interpersonal communication is face to face interaction within two people or some pepople, sender could deliver message directly, and message receiver could receive and respond directly. According to Arni Muhammad (2007:159) interpersonal communication is a process of changing information between someone within less then a person or other, or usually between two person that directly are known its reversed.

Researcher synthesizes interpersonal communication is a social process which peoples that are involved influence, and are the more effective communication in changing behavior, idea, opinion, thought, or someone behavior in organization, through indicators : (1) transparancy, (2) emphaty, (3) support, (4) positive behavior, and (5) equality.

\section{Organizational Commitment}

L. Mathis-John H. Jackson (2012), organizational commitment is a level which employee is sure and accept organizational purpose, and also willing to stay together or leave the company at the end are reflected in absence and employee rotation number. The definition of organizational commitment also is developed by Meyer and Allen (1993), Curtis and Wright (2001), Fred Luthan (2005) and S.G.A. Smeenk, et al., (2006). Based on the opinion of experts, researcher synthesizes organizational commitment is concerness that is shown by certain person to organization and willingnes to stay in an active participate at that organization through indicators : (1) affective commitment, (2) continuity commitment, and (3) normative commitment.

\section{Earlier Research}

Research about the influence of transformational leadership to public service quality had been done by AlaDeen Mah'd Alloubani, Mohammad Almatari, and Mohammad Musa Almukhtar (2014), Susanne Braun, Claudia Peus, Silke Weisweiler, \& Dieter Frey (2013:270-283), Waqas Umer Malik, Muqaddas Javed, \& Syed Taimoor Hassan (2017:146$165)$.

Research about the influence of interpersonal communication to public service quality had been done by research of R. Surya Saptaraharja (2012). Research about the influence of organizational commitment to public service quality had been done by Ogunnaike, Olaleke. Oluseye (2011), Mohammad Reza Azadehdel, Mehrdad Goudarzvand Chegini, dan Mahyar Delshad (2013).

Research about the influence of transformational leadership to public service quality had been done by Susi Milwati (2013). Research about the influence of interpersonal communication to organizational commitment had been done by Tiur Asi Siburian (2013), Benyamin Situmorang (2012). Generally the result of research show that transformational leadership, interpersonal communication and organizational commitment take a real effect to quality of some services (public service quality).

\section{METHODOLOGY}

Research use quantitative approach. Population in research is divided into two, i.e external and internal. External population is all visitor that come to Public Service Unit, Internal population is monitoring officials (eselon IV) of BNP2TKI, BP3TKI/LP3TKI/P4TKI.

Population of eselon IV official of BNP2TKI total 214 officials, so are obtained the sample amount in this research is 140 respondents. Sampling method that is used is systematic random sampling. Analyze method in this research is determined to two i.e descriptive and inferential statistics through path analysis. $T$ test is used to test the influence of independent variable to dependent variable. $F$ test is used to test appropriateness level from result model. 
Variable is defined as whatever it could differentiate or take variation to value. Value could be different from time to time for object or same people or at the same time to different object (Sekaran, U. \& Bougie, R., 2010). Variable in this research is divided into 4 (four) variable i.e public service quality, transformational leadership, interpersonal communication and organizational commitment.

Table 1. Operational variable

\begin{tabular}{|l|l|l|l|}
\hline No. & Variable & Indicator & Reference \\
\hline 1 & $\begin{array}{l}\text { Public service } \\
\text { quality }\end{array}$ & $\begin{array}{l}\text { Tangible } \\
\text { Reliability } \\
\text { Responsiveness } \\
\text { Assurances } \\
\text { Empathy }\end{array}$ & $\begin{array}{l}\text { Zeithaml, and } \\
\text { Berry } \\
\text { In Journal of } \\
\text { Retailing (1998) }\end{array}$ \\
\hline 2 & $\begin{array}{l}\text { Transformational } \\
\text { Leadership }\end{array}$ & $\begin{array}{l}\text { Idealized influence } \\
\text { Inspirational motivation } \\
\text { Intellectual stimulation } \\
\text { Individual consideration }\end{array}$ & $\begin{array}{l}\text { Bass and Avolio } \\
(1993)\end{array}$ \\
\hline 3 & $\begin{array}{l}\text { Interpersonal } \\
\text { communication } \\
\text { Emphaty } \\
\text { Support } \\
\text { positive behavior } \\
\text { equality }\end{array}$ & $\begin{array}{l}\text { Devito (2011) } \\
\text { Affective commitment } \\
\text { Continuity commitment } \\
\text { Normative commitment }\end{array}$ & $\begin{array}{l}\text { Robbins } \\
\text { Judge (2014 and }\end{array}$ \\
\hline 4 & $\begin{array}{l}\text { Organizational } \\
\text { commitment }\end{array}$ &
\end{tabular}

\section{Hypothesis}

H1: Transformational leadership $\left(\mathrm{X}_{1}\right)$ take a direct effect to public service quality $\left(\mathrm{Y}_{2}\right)$.

H2: Interpersonal communication $\left(\mathrm{X}_{2}\right)$ take a direct effect to public service quality $\left(\mathrm{Y}_{2}\right)$.

H3: Organizational commitment $\left(\mathrm{Y}_{1}\right)$ take a direct effect to public service quality $\left(\mathrm{Y}_{2}\right)$.

H4: Transformational leadership $\left(\mathrm{X}_{1}\right)$ take a direct effect to organizational commitment $\left(\mathrm{Y}_{1}\right)$.

H5: Interpersonal communication $\left(\mathrm{X}_{2}\right)$ take a direct effect to organizational commitment $\left(\mathrm{Y}_{1}\right)$.

H6: Transformational leadership $\left(\mathrm{X}_{1}\right)$ take a direct effect to interpersonal communication $\left(\mathrm{X}_{2}\right)$

H7: Transformational leadership $\left(\mathrm{X}_{1}\right)$ take an indirect effect to public service quality $\left(\mathrm{Y}_{2}\right)$ through organizational commitment $\left(\mathrm{Y}_{1}\right)$

H8: Interpersonal communication $\left(\mathrm{X}_{2}\right)$ take an indirect effect to public service quality $\left(\mathrm{Y}_{2}\right)$ through organizational commitment $\left(\mathrm{Y}_{1}\right)$

\section{RESULT AND DISCUSSION}

Amount of respondent for each category is 140 respondents. Internal respondent characteristic is based on gender, age, marital, education, working period and the amount of dependent. Majority respondent is man $(56,4 \%)$, age $30-45$ year $(74,3 \%)$, has been married $(91,4 \%)$, undergraduate education background $(73,6 \%)$ with working period more than eight years $(86,4 \%)$.

Table 2. Internal Respondent Profile

\begin{tabular}{|l|l|l|}
\hline Note & Frequency & Percentage \\
\hline Respondent Gender & 79 & $56,4 \%$ \\
\hline Man & 51 & $43,6 \%$ \\
\hline Woman & \multicolumn{2}{|l|}{} \\
\hline Respondent Age & 4 & $2,9 \%$ \\
\hline$<30$ year
\end{tabular}




\begin{tabular}{|l|l|l|}
\hline Note & Frequency & Percentage \\
\hline $30-45$ year & 104 & $74,3 \%$ \\
\hline$>$ 45 year & 32 & $22,9 \%$ \\
\hline Marital Status & 7 & $5 \%$ \\
\hline Bachelor & 128 & $91,4 \%$ \\
\hline Married & 5 & $3,6 \%$ \\
\hline Not Married & \multicolumn{2}{|l|}{} \\
\hline Latest Education Background & $0,7 \%$ \\
\hline Diploma & 1 & $73,6 \%$ \\
\hline Undergraduate & 103 & $25,6 \%$ \\
\hline Post graduate & 36 & $2,1 \%$ \\
\hline Working Period & 3 & $11,4 \%$ \\
\hline$<4$ year & 16 & $86,4 \%$ \\
\hline 4-8 year & 121 & $31,4 \%$ \\
\hline$>8$ year & 44 & $32,1 \%$ \\
\hline The amount of dependants & $36,4 \%$ \\
\hline 1 person & 45 \\
\hline 2 person & 51 \\
\hline$>2$ person &
\end{tabular}

External respondent characteristic is based on gender characteristic, age, marital status and latest educational background. This research show that the majority of external respondent is man $(70,7 \%)$ within age less than 30 year $(50,7 \%)$, has married $(59,3 \%)$ and latest educational background is Senior Highschool/equal $(72,1 \%)$.

Table 3. External Respondent Profile

\begin{tabular}{|l|l|l|}
\hline Note & $\begin{array}{l}\text { Frequency } \\
\text { (respondent) }\end{array}$ & $\begin{array}{l}\text { Percentage } \\
(\%)\end{array}$ \\
\hline Responden Gender & 99 & $70,7 \%$ \\
\hline Man & 41 & $29,3 \%$ \\
\hline Woman & 71 & $50,7 \%$ \\
\hline Respondent Age & 58 & $41,4 \%$ \\
\hline$<30$ year & 11 & $7,9 \%$ \\
\hline 30-45 year & 54 & $38,6 \%$ \\
\hline$>45$ year & 83 & $59,3 \%$ \\
\hline Marital Status & 3 & $2,1 \%$ \\
\hline Bachelor & \\
\hline Married & 101 & $72,1 \%$ \\
\hline Not Married & \\
\hline Latest Educational Background & \\
\hline $\begin{array}{l}\text { < Senior } \\
\text { High school/Religion } \\
\text { Senior High school }\end{array}$ & \multicolumn{2}{|l|}{} \\
\hline Diploma & 10 & $20,7 \%$ \\
\hline$>$ Undergraduate & 29 & \\
\hline
\end{tabular}

Eight hypothesis are tested in this research. Hypothesis is tested to measure direct influence and indirect influence independent variable to dependent variable. Test statistic that is used is t test. Independent Variable is stated having significant influence to dependent variable if having t-count value bigger than t table or having significant less then $\alpha$ value $=$ 0,05 . The result of hypothesis testing is served at table 1 . 
Table 4. Hypothesis Testing

\begin{tabular}{lccccc}
\hline No. & $\begin{array}{l}\text { Direct } \\
\text { Influence }\end{array}$ & $\begin{array}{l}\text { Path } \\
\text { Coefficient }\end{array}$ & Db & $\mathbf{T}_{\text {count }}$ & $\begin{array}{l}\mathbf{t}_{\text {table }} \\
\boldsymbol{\alpha}=\mathbf{0 , 0 5}\end{array}$ \\
\hline 1. & $\mathrm{X}_{1}$ to $\mathrm{Y}_{2}$ & 0,343 & 136 & 5,13 & 1,98 \\
\hline 2. & $\mathrm{X}_{2}$ to $\mathrm{Y}_{2}$ & 0,300 & 136 & 4,51 & 1,98 \\
\hline 3. & $\mathrm{Y}_{1}$ to $\mathrm{Y}_{2}$ & 0,293 & 136 & 4,25 & 1,98 \\
\hline 4. & $\mathrm{X}_{1}$ to $\mathrm{Y}_{1}$ & 0,280 & 137 & 3,52 & 1,98 \\
\hline 5. & $\mathrm{X}_{2}$ to $\mathrm{Y}_{1}$ & 0,273 & 137 & 3,43 & 1,98 \\
\hline 6. & $\mathrm{X}_{1}$ to $\mathrm{X}_{2}$ & 0,262 & 138 & 3,19 & 1,98 \\
\hline
\end{tabular}

The result of this kind testing shows that the testing result at hypothesis 1 to hypothesis 6 is proven. The value of $t_{\text {-count }}$ is bigger than the value of $t$-table, so could be concluded that there is a positive direct influence and significant from independent variable to dependent variable.

1. Transformational Leadership has direct influence and positive to Public service quality, with influence Coefficient in the amount of 0,343.

2. Interpersonal communication has direct influence and positive to Public service quality, with influence Coefficient in the amount of 0,300.

3. Organizational Commitment has direct influence and positive to Public service quality, with influence Coefficient in the amount of 0,293.

4. Transformational Leadership has direct influence and positive to Organizational Commitment, with influence Coefficient in the amount of 0,280.

5. Interpersonal communication has direct influence and positive to Organizational Commitment, with influence Coefficient in the amount of 0,273.

6. Transformational Leadership has direct influence and positive to Interpersonal communication, with influence Coefficient in the amount of 0,262.

7. Transformational Leadership has indirect influence and positive to Public service quality through Organizational Commitment with influence Coefficient in the amount of 0,082 $(0,280 \times 0,292=0.082)$.

8. Interpersonal communication has indirect influence and positive to Public service quality through Organizational Commitment with influence Coefficient in the amount of 0,067 $(0.23 \times 0.293=0.067)$.

Path analysis is divided into 3 model. First is the influence of transformational leadership model $\left(\mathrm{X}_{1}\right)$, interpersonal communication $\left(\mathrm{X}_{2}\right)$ and organizational commitment $\left(\mathrm{Y}_{1}\right)$ to Public service quality $\left(\mathrm{Y}_{2}\right)$. Second is the influence of transformational leadership model $\left(\mathrm{X}_{1}\right)$, Interpersonal communication $\left(\mathrm{X}_{2}\right)$ to Organizational Commitment $\left(\mathrm{Y}_{1}\right)$. Third is the influence of transformational leadership model $\left(\mathrm{X}_{1}\right)$ to Interpersonal communication $\left(\mathrm{X}_{2}\right)$.

The result of this kind modelling at first model could be obtained determination coefficient value (R-Square) in the amount of 0,479 and path equation: $\mathrm{Y}_{2}=0,343 \mathrm{X}_{1}+$ $0,300 \mathrm{X}_{2}+0,293 \mathrm{Y}_{1}+\varepsilon_{1}$.

First Model show that public service quality $\left(\mathrm{Y}_{2}\right)$ in BNP2TKI is mostly influenced by transformational leadership $\left(\mathrm{X}_{1}\right)$ with influence coefficient in the amount of 0,343 , then is followed by interpersonal communication $\left(\mathrm{X}_{2}\right)$ with influence coefficient in the amount of 0,300 and organizational commitment $\left(Y_{1}\right)$ with influence coefficient in the amount of 0,293.

The result of this kind modelling at second time could be obtained determination coefficient value (R-Square) in the amount of 0,193 and path equation: $\mathrm{Y}_{1}=0,280 \mathrm{X}_{1}+$ $0,273 \mathrm{X}_{2}+\varepsilon_{2}$

The second model show that organizational commitment $\left(\mathrm{Y}_{1}\right)$ in BNP2TKI is more influenced by transformational leadership $\left(X_{1}\right)$ with coefficient in the amount of 0,280 and then Interpersonal communication $\left(\mathrm{X}_{2}\right)$ with coefficient in the amount of 0,273.

The result of this kind modelling at the third could be obtained determination coefficient value (R-Square) in the amount of 0,0688 and path equation: $X_{2}=0,262 X_{1}+\varepsilon_{3}$ 
Third Model shows interpersonal communication $\left(\mathrm{X}_{2}\right)$ is influenced by transformational leadership $\left(\mathrm{X}_{1}\right)$ with path coefficient in the amount of 0.262 . Path model at this research is served at figure 1 .

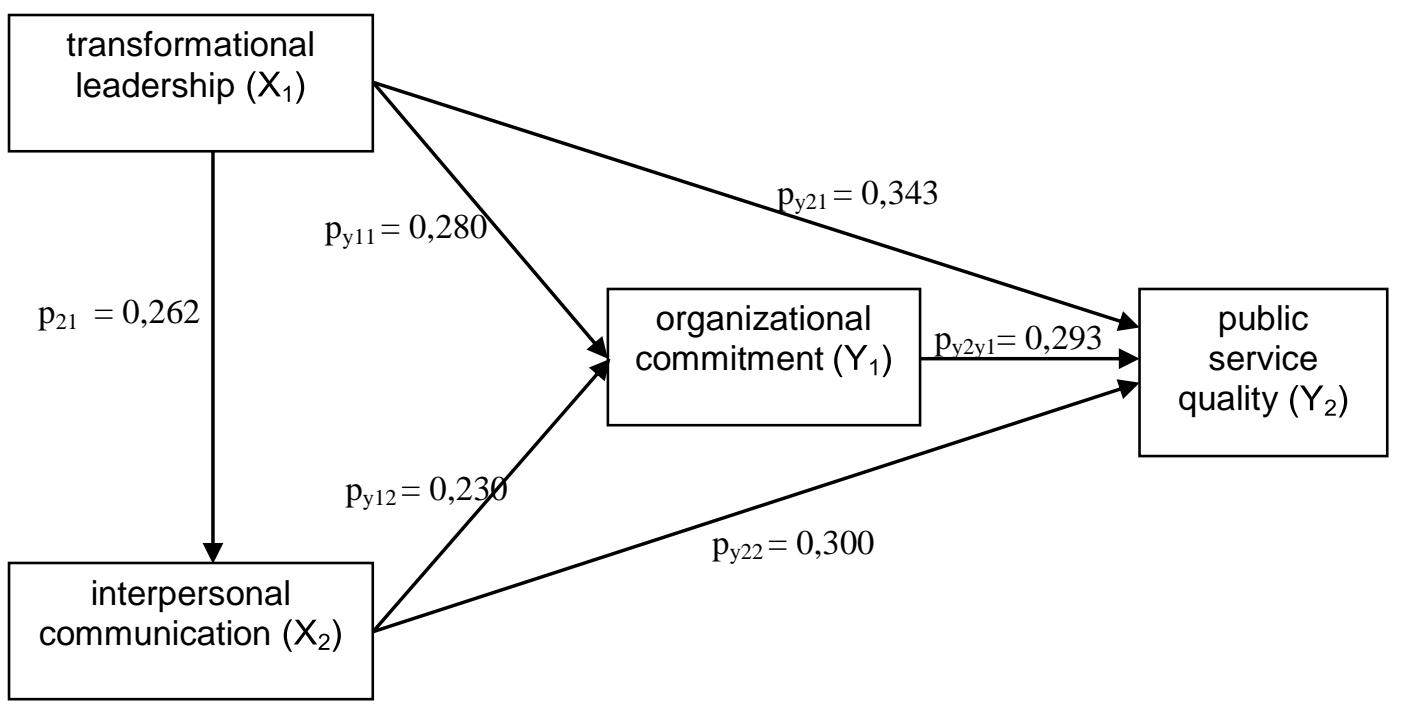

Figure 1. Diagram Empiric Path of All Research Model

The result of first hypothesis produce a finding that transformational leadership has direct influence and positive to public service quality. The increasing of transformational leadership will cause the increasing of public service quality. The result of this research is as the same of the opinion from some experts, one of them is Sondang P. Siagian (2012), leadership is factor motor then all resources and tool that are given for organization. Leadership is main idea, purpose, plan, organize, drive and control all resource that is owned, so the goal from organization could be achieved with and also effective and efficient. BNP2TKI Leader is demanded to always able create a condition that satisfy subordinate in working period.

Public service quality is influenced positively by Interpersonal communication. The increasing of Interpersonal communication will cause the increasing of public service quality. The result of this research is as the same of the opinion from some experts, one of them is Joseph Devito, (2010) "The effectiveness of interpersonal communication in a humanistic view contains elements of openness, empathy, supportive attitudes, positive attitudes, and similarities". Interpersonal communication that is created between BNP2TKI employee with public is important term in building the perception of service quality that is given by BNP2TKI to public.

Hypothesis Test conclude that public service quality is influenced positively by Organizational Commitment. The increasing of Organizational Commitment will cause the increasing of public service quality. The result of this research is as the same of the opinion from Syed Muhammad Azeem (2014) in his research explained: "Organizational commitment due to the opportunities for the public sector employees to advance their career". Every employee has a different base and behavior depend on Organizational Commitment it owned. Employee that has a high commitment will do maximum effort and strong willingness to achieve the purpose of organization. Employee that has a low commitment will do minimum effort and also full of compulsion.

Organizational Commitment is influenced by transformational leadership. Strong transformational leadership will cause the increasing of organizational commitment. The result of this research is as the same of the opinion from Wibowo (2012) basically a manager could do operational commitments and transformational commitments. By running 
operational commitments, a manager maintain status quo, such as budget aggrement, working task, or consumer guarantee.

Organizational Commitment is influenced positively by interpersonal communication. The increasing of interpersonal communication will cause the increasing of organizational commitment. The result of this research is as the same of the opinion from some experts, one of them is Onong Uchjana Effendy (1986) that stated interpersonal communication is communication betwee manager and other communicant inside organization i.e employee reciprocally.Interpersonal communication is influenced positively by Transformational Leadership.

The increasing of transformational leadership will cause the increasing of interpersonal communication. The result of this research is as the same of the opinion from some experts, one of them is Siagian (2012) that, "leadership role consist of : interpersonal, informational, and decision making". Transformational Leadership is the key and main priority in the effort to increase public service quality in BPN2TKI. Beside having the highest direct influence to public service quality also having indirect influence through interpersonal communication and organizational commitment.

\section{CONCLUSION}

The result of hypothesis testing become basic in organized conclusion at this research. The research of this research as follows: transformational Leadership has direct influence and positive to public service quality, interpersonal communication and organizational commitment. Transformational Leadership that has been good applied could cause the increasing of public service quality, interpersonal communication and also of Organizational Commitment at BNP2TKI institution.

Interpersonal communication has direct influence and positive to public service quality and organizational commitment. It means that Interpersonal communication that has been good applied could cause the increasing of public service quality and also of Organizational Commitment at BNP2TKI institution. Organizational Commitment has direct influence and positive to public service quality. Organizational Commitment that has been good applied could cause the increasing of public service quality at BNP2TKI.

Transformational Leadership has indirect influence and positive to public service quality through Organizational Commitment. It means that Transformational Leadership that has been good applied could cause the increasing of public service quality to BNP2TKI directly or indirectly. Interpersonal communication has indirect influence and positive to public service quality through Organizational Commitment. The good interpersonal communication from all leader and employee could cause the increasing of public service quality to BNP2TKI directly or indirectly.

\section{REFERENCES}

Allen, Natalie J. and John P. Meyer, (1993). Organizational commitment: Evidence of career stage effects?. Journal of Business Research, 26.

Alloubani, AlaDeen Mah'd, Mohammad Almatari, dan Mohammad Musa Almukhtar, (2014). Review: Effects of Ledership Styles on Quality of Services in Healthcare, European Scientific Journal, June 2014 Edition vol. 10, No. 18

Ancok, Djamaludin, (2012). Psikologi Kepemimpinan dan Inovasi. Jakarta: Erlangga.

Aras, Güler \& David Crowther. (2008). Governance and sustainability: An investigation into the relationship between corporate governance and corporate sutainalibity. Journal of Management Decision. Vol. 46 Iss 3, pp. 433-448.

Azeem. S.M \& Akhtar.N. (2014). Job Satisfaction and Organizational Commitment among Public Sector Employees in Saudi Arabia. Internationa Journal of Business and Social Science Vol 5.No 7; June 2014. 
Bass, Bernard M. \& Ronald E. Reggio, (2006). Transformational Leadership. London: Lawrence New Jersey.

Bass, B.M., and Avolio, B.J. 1993. Transformational Leadership and Organizational Culture. Public Administration Quarterly, Vol. 17.

Bertocci, David I, (2009). Leadershipin OrganizationsThere Is a Difference between Leaders and Managers. USA, University Press of America, Inc.

Braun, Susanne, Claudia P, Silke W \& Dieter F., (2013), Transformational leadership, job satisfaction, and team performance: A multilevel mediation model of trust, The Leadership, Quarterly 24.

Colquitt, Jason A., (2011). Organizational Behavior, Improving Performance and Commitment in the Workplace, McGraw-Hill.

Curtis, Susan dan Dennis Wright, (2001). Retaining Employees - The Fast Track to Commitment. Management Research News, Volume 24.

Daft, Richard L, (2008). The Leadership Experience, United States of America: Thomson South-Western.

Devito, Joseph A. (2011), Komunikasi Antarmanusia: Kuliah Dasar, Professional Book, Jakarta.

Dubrin, Andrew J. (2009). The Complete Ideas Guides Leadership, Jakarta:Alpha Books.

Effendi, Onong Uchjana, (2002), Dimensi-dimensi Komunikasi. Alumni, Bandung: Remadja Karya.

Fahmi, Irham, (2002). Manajemen kepemimpinan, Teori dan Aplikasi. Bandung: Alfabeta.

Fattah, Nanang, (2008). Landasan Manajemen Pendidikan. Bandung: PT. Remaja Rosdakarya.

Gronroos, C. (1984), A service quality model and its marketing implications. European Journal of Marketing, Vol. 18.

Hardiansyah, (2014). Dominance Factor Which Impact to Public Service Quality, blog.binadarma.ac.id/hardiyansyah/?p=25, accessed March $27^{\text {th }} 2014$.

Hardjana, Agus M. (2003), Komunikasi Intrapersonal dan Interpersonal, Yogyakarta : Kanisius.

Kartono, Kartini, (2003) Pemimpin dan Kepemimpinan, Apakah Pemimpin abnormal itu?. Penerbit PT Raja Grafindo Persada, Jakarta.

Kotler, Philip, (2002). Manajemen Pemasaran di Indonesia: Analisis, Perencanaan, Implementasi dan Pengendalian. Salemba Empat, Jakarta.

Kreitner, Robert \& Angelo Kinicki, (2003). Organisational behaviour (6th ed). New York, NY: McGraw-Hill.

Lee A., Martin R., Thomas G., Fuillaume Y. \& Maio G. R., (2015). Conceptualizing leadership perceptions as attitudes: Using attitude theory to further understand the leadership process. The Leadership Quarterly. http://dx.doi.org/10.1016/j.leaqua.2015.10.003

Luthans, Fred, (2011). Organizational Behavior Fred Luthans an Evidence-Based Approach, McGraw-Hill/Irwin, New York, $12^{\text {th }} E d$.

Parasuraman, A., Valarie A. Zeithaml, dan Leonard L. Berry, (1998). SERVQUAL: A Multiple-Item Scale for Measuring Consumer Perceptions of Service Quality. Journal of Retailing, Vol. 64, No. 1.

Rahardjo, Mudji dan Purbudi, (1997). Manajemen Sumber Daya Manusia. Yogjakarta: UPN. Robbins, S.P dan Judge T.A., (2015). Perilaku Organisasi. Jakarta: Salemba Empat.

Sekaran, U., \& Bougie, R. (2010). Research methods for business: A skill-building approach (5th ed.). Haddington: John Wiley \& Sons.

Siagian, Sondang P. (2012). Teori dan Praktek Kepemimpinan (5th ed), Jakarta: Rineka Cipta.

Wibowo. (2012). Manajemen Perubahan (3th Ed). Jakarta: PT RajaGrafindo Persada. 